\title{
Advanced wearable thermo-cells for body heat harvesting
}

Yuqing Liu ${ }^{1,2+}$, Shuai Zhang ${ }^{2+}$, Yuetong Zhou ${ }^{2}$, Mark A. Buckingham ${ }^{3}$, Leigh Aldous ${ }^{3}$, Peter C. Sherrell ${ }^{4}$, Gordon G. Wallace, ${ }^{2,}$, Gregory Ryder ${ }^{2}$, Shaikh Faisal ${ }^{2}$, David L. Officer ${ }^{2}$, Stephen Beirne ${ }^{2}$, and Jun Chen $^{2, *}$

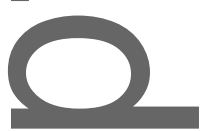

( The authors contribute equally to this work)

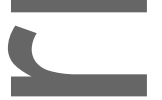

Dr. Y. Liu

State Key Laboratory of Electronic Thin Film and Integrated Devices

University of Electronic Science and Technology of China

Chengdu, 610054, PR China.

Dr. Y. Liu, S. Zhang, Y. Zhou, Prof. G. G. Wallace, Dr. G. Ryder, Dr. S. Faisal, Prof. D. L. Officer, Prof. S. Beirne, Prof. J. Chen

Intelligent Polymer Research Institute and ARC Centre of Excellence for Electromaterials Science, Australian Institute for Innovative Materials

University of Wollongong

Wollongong, NSW 2500, Australia

E-mail: junc@uow.edu.au and gwallace@uow.edu.au

M. A. Buckingham, Dr. L. Aldous,

Department of Chemistry, Britannia House

King's College London

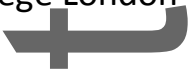

This is the author mal uscript accepted for publication and has undergone full peer review but has not

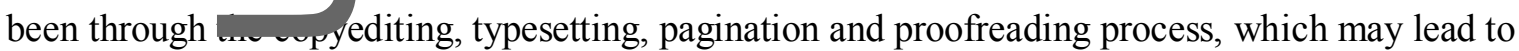
differences betwe the version and the Version of Record. Please cite this article as doi: $\underline{10.1002 / \mathrm{a}-11.201} 0.02539$.

This article is protected by copyright. All rights reserved. 


\section{WILEY-VCH}

London, SE1 1DB, UK

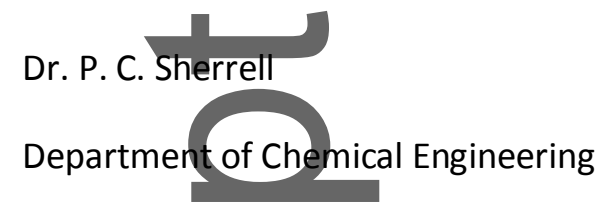

The University of Melbourne

Parkville, Victoria 3010, Australia

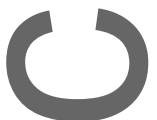

Keywords: thermo-cells, body heat, gel electrolyte, electrode/electrolyte integration

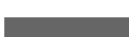

Abstract: Thermo-electrochemical cells (thermo-cells) designed for harvesting human body heat can provide a constant power output for wearable electronics, supplementing state-of-the-art flexible power storage and conversion solutions. However, a systematic investigation into the optimization of wearable thermo-cells is lacking, especially with regard to device design, n-type electrolytes, and electrode/electrolyte integration. Here, a n-type gel electrolyte: polyvinyl alcohol (PVA)- $\mathrm{FeCl}_{2 / 3}$ with outstanding flexibility and elasticity is produced, which demonstrates exceptional electrolyte/electrode integration into a 3D porous poly(3,4ethylenedioxythiophene)/polystyrenesulfonate (PEDOT/PSS) electrode via an in-situ chemical crosslinking method. The integrated $n$-type cell shows excellent seebeck coefficients $\left(0.85 \mathrm{mV} \mathrm{K}^{-1}\right)$ and output current density $\left(1.74 \mathrm{~A} \mathrm{~m}^{-2} \mathrm{~K}^{-1}\right)$ that are comparable with an optimized p-type cell consisting of a carboxymethylcellulose $(\mathrm{CMC})-\mathrm{K}_{3 / 4} \mathrm{Fe}(\mathrm{CN})_{6}$ electrolyte with a 3D PEDOT/PSS-edge functionalized graphene/carbon nanotube(PEDOT/PSS-EFG/CNT) electrode (-1.22 $\mathrm{mV} \mathrm{K}^{-1}$ and $1.85 \mathrm{~A}$ $\left.\mathrm{m}^{-2} \mathrm{~K}^{-1}\right)$. The equivalent performance of the $\mathrm{n}$-type and $\mathrm{p}$-type cells enables the effective series connection of up to 18 pairs of $p$-n cells that combines to give an output voltage of $0.34 \mathrm{~V}(\Delta \mathrm{T}=10$

This article is protected by copyright. All rights reserved. 


\section{WILEY-VCH}

K). This in-series device is fabricated into a proof-of-concept watch strap, which can harvest body heat, charge supercapacitor (up to $470 \mathrm{mF}$ ) as well as illuminate a green LED, clearly demonstrating the practical application.

1. Introduction

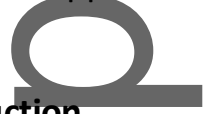

$\square$

The emergence of wearable electronic devices has stimulated the demand for a flexible, light-weight and high-efficiency power supply system. ${ }^{[1,2]}$ In contrast to more traditional energy storage systems (e.g. batteries ${ }^{[3]}$ and supercapacitors ${ }^{[4]}$ ), which require manual recharging, flexible energy harvesters (including solar cells, ${ }^{[5]}$ piezoelectric polymer generators, ${ }^{[6,7]}$ triboelectric generators $^{[8,9]}$ and thermoelectric generators ${ }^{[10-13]}$ ) convert energy from the local environment, including mechanical motion or temperature gradients from the human body, to electrical charge. ${ }^{[14,15]}$ These energy harvesters are environmentally friendly power sources, which potentially provide a pathway towards the elimination of manual device charging and a reduction in battery waste. ${ }^{[10]}$ Among these power sources, thermoelectric generators (TEG) attached to the human body are highly attractive, as the heat continually being emitted by the body (up to $20 \mathrm{~mW} / \mathrm{cm}^{2}$ ) enables a constant power supply, in contrast to motion-based, or solar-based energy harvesting technologies. ${ }^{[10-13,16,17]}$ We have recently discussed the promising prospect of body heat harvesting in the future global market of wearable electronics and provided possible designs for a skin-conformal TEG. ${ }^{[10]}$ However, relatively low figures of merit (such as the Seebeck coefficient, $\mathrm{S}_{\mathrm{e}}=\Delta \mathrm{V} / \Delta \mathrm{T}$, which is typically on the order of $\mu \mathrm{V} \mathrm{K}$ $\left.{ }^{1}\right)^{[18]}$ and the reliance on rigid and expensive thermoelectric materials have greatly limited the practical development of TEGs for wearable applications. ${ }^{[10]}$ Thermo-electrochemical cells (thermocells, TECs) harvest thermal energy through the temperature-dependent electron transfer between redox couples and electrodes, and typically exhibit much higher Seebeck coefficients (on the order

This article is protected by copyright. All rights reserved. 


\section{WILEY-VCH}

of $\mathrm{mV} \mathrm{K}^{-1}$ ) than TEGs. ${ }^{[18]}$ Thermo-cells have a simple structure and can be fabricated from inexpensive materials, making them ideal candidates for low-grade heat harvesting (e.g. body heat) for wearable technologies. ${ }^{[18-20]}$ Thermo-cells are also extremely attractive as they can constantly generate energy, provided there is a suitable thermal gradient, without any toxic emissions or chemical waste.

Great progress has been made in flexible and wearable thermo-cells, however, this progress has focused on two main aspects: flexible electrodes ${ }^{[20-22]}$ and leak-free gel electrolytes. ${ }^{[23-25]}$ To prepare flexible electrodes, inexpensive carbon-based materials or conducting polymers are often used instead of traditional and expensive platinum electrodes. The first report of flexible electrodes for wearable TECs used an activated carbon textile (ACT) coated with carbon nanotubes (CNTs). ${ }^{[20]}$ Further investigations built on this platform using free-standing carbon-based materials (e.g. graphene/CNT films, ${ }^{[21,26]}$ MWNT foam, ${ }^{[22,27]}$ activated carbon cloth, ${ }^{[22]}$ CNT/PtNPs aerogel ${ }^{[27]}$ and others) and confirmed that higher surface areas, electrocatalytic behavior, enhanced porosity, and improved electrical conductivity are key considerations to achieve substantial advances in thermocell performance. In addition, the charge carrier electrolyte has been the subject of intensive development, with a focus on the development of gel electrolytes with no solvent leakage for wearable application. ${ }^{[28]}$ In gel electrolytes, the selection of a suitable polymer for the redox active species plays the most important role. The polymer needs to provide a mechanical matrix sufficient to prevent solvent leakage but also have a high diffusion coefficient (on the order of $10^{-5} \mathrm{~cm}^{2} \mathrm{~s}^{-1}$ ) of redox couples to enable sufficient transport. For the $\left[\mathrm{Fe}(\mathrm{CN})_{6}\right]^{3-/ 4-}$ redox system, various watersoluble polymers (agar agar, ${ }^{[23]}$ gelatin, ${ }^{[23]}$ poly(sodium acrylate), ${ }^{[23]}$ polyvinyl alcohol ${ }^{[19,24]}$ and celluloses $^{[24]}$ ) have been explored, where gelation was induced by cooling down a hot mixture

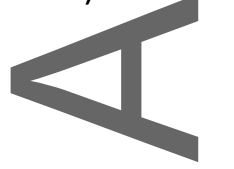

This article is protected by copyright. All rights reserved. 


\section{WILEY-VCH}

containing $\left[\mathrm{Fe}(\mathrm{CN})_{6}\right]^{3-/ 4-}$ and a polymer. Polyanions with carboxyl functional groups, including poly (sodium acrylate) ${ }^{[23]}$ and carboxymethylcellulose $(\mathrm{CMC}),{ }^{[24]}$ are able to form gels containing high concentrations of $\left[\mathrm{Fe}(\mathrm{CN})_{6}\right]^{3-14-}$ (as high as $0.4 \mathrm{M}$ ). In addition, superabsorbent polymer hydrogels (like polyacrylamide) ${ }^{[24]}$ or polymer films (e.g. cellulose) ${ }^{[25]}$ can also be immersed in the aqueous redox electrolyte and produce a gel electrolyte. Optimizing the weight percentage of the polymer is crucial to balance the mechanical properties and enable fast ion transport. However, all previous reports are independent studies on either the electrode or the electrolyte. There have been no reports of a system where advanced electrodes are coupled to new, optimized, gel electrolytes; this is crucial as the interfacial properties, specifically wettability and charge transport phenomena, vary dramatically between traditional metal and the advanced carbon-based electrodes.

To date, developments in thermo-cells have focused on optimization for individual cells. However, with appropriate design considerations, single cells with alternating negative and positive Seebeck coefficients can be coupled in series to form an array that improves the overall output voltage for practical applications (Figure 1). ${ }^{[19,29,30]}$ These arrays of thermo-cells are analogous to the $p$ - and $n$ doped TEGs, and therefore denoted as $p$-type and $n$-type thermo-cells in this manuscript. The output current of p-n cells connected in series (denoted as p-n cells) is limited by the lowest current of the individual single cells, so it is of vital importance to match the current output for both $p$-type and ntype half-cells for efficient and optimal performance. ${ }^{[30]}$ It is noted that most of the literature on TECs is focused on the development of $p$-type electrolytes (where the absolute charge of the oxidant is smaller than the reductant), often based on $\left[\mathrm{Fe}(\mathrm{CN})_{6}\right]^{3-/ 4-}$, with only a few reports focused on fabrication of $n$-type gel electrolytes (where the absolute charge of the oxidant is larger than the reductant). ${ }^{[18,30]}$ The performance of $n$-type cells with either aqueous ${ }^{[31,32]}$ or gelled

This article is protected by copyright. All rights reserved. 


\section{WILEY-VCH}

electrolytes ${ }^{[19,33,34]}$ are intrinsically lower than p-type cells in terms of current due to sluggish kinetics. ${ }^{[18]}$ For example, Aldous et al. investigated the fundamentals of combining the conventional $\left[\mathrm{Fe}(\mathrm{CN})_{6}\right]^{3-/ 4-2}$ p-type thermo-cell with Fe(II/III) sulfate as an n-type thermo-cell, both electrically inseries and in-parallel. ${ }^{[30]}$ Zhou et al. mixed polyvinyl alcohol with $\mathrm{FeCl}_{2 / 3}$ as an n-type thermo-cell, and coupled it with a $0.02 \mathrm{M}\left[\mathrm{Fe}(\mathrm{CN})_{6}\right]^{3-/ 4-}$ redox couple as a p-type cell. ${ }^{[19]}$ Kimizuka et al. prepared a polysaccharide $/ \mathrm{I}_{2} \mathrm{~d}_{3}$ n-type gel electrolyte and improved the Seebeck coefficient from +0.86 to +1.5 $\mathrm{mV} \mathrm{K}^{-1}$ by introducing polymer-ion interactions. ${ }^{[33]}$ Pringle et al. prepared the first aqueous gel electrolyte based on a cobalt redox couple, $\mathrm{Co}(\mathrm{bpy})_{3} \mathrm{Cl}_{2 / 3}$, using a cellulose film as the polymer matrix, which exhibits a Seebeck coefficient of $+1.21 \mathrm{mV} \mathrm{K}^{-1} \cdot{ }^{[34]}$ Despite these efforts, the best reported output current and power for n-type cells is still one order of magnitude lower than the $p$ type cells. In addition to the electrolyte, flexible electrodes which can catalyze the redox reaction of $\mathrm{n}$-type couples has hot been well studied in detail to date. Therefore, the study on the n-type cells in terms of both the electrode and gel electrolyte is a key challenge to develop effective $p$-n cells and produce efficient integrated arrays of $p-n$ cells.

In this work, we systematically investigated the performance of both p-type and n-type thermocells through study and optimization of both the flexible electrode and gel electrolyte, enabling the development of high performance $p$-n cell arrays for practical body-heat energy harvesting applications (as illustrated in Figure 1). Firstly, to address the relatively low performance of n-type devices, we systematically prepared a flexible and stretchable n-type gel electrolyte ( $\left.\mathrm{PVA}-\mathrm{FeCl}_{2 / 3}\right)$. This PVA- $\mathrm{FeCl}_{2 / 3}$ electrolyte can accommodate a wide range of $\mathrm{FeCl}_{2 / 3}$ concentrations (0.1 $\mathrm{M}$ to $2 \mathrm{M}$ ) without affecting the gelation process and maintaining the thermo-electrochemical performance of the $\mathrm{Fe}^{2+} / \mathrm{Fe}^{3+}$ redox couple. This $\mathrm{n}$-type gel electrolyte demonstrated comparable performance with

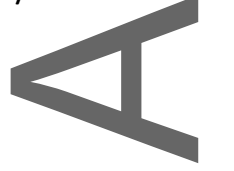

This article is protected by copyright. All rights reserved. 


\section{WILEY-VCH}

the previously developed p-type electrolyte of carboxymethyl cellulose $(\mathrm{CMC})-\mathrm{K}_{3 / 4} \mathrm{Fe}(\mathrm{CN})_{6}$ with $\mathrm{Pt}$ electrodes. ${ }^{[24]}$ The performance of both p-type and n-type cells was optimized using 3D structured poly(3,4-ethylenedioxythiophene)/polystyrenesulfonate-edge functionalised graphene/carbon nanotubes (PEDOT/PSS-EFG/CNT) and PEDOT/PSS film electrodes, respectively. A pair of p-type and $n$-type TECS (p-n cells) with comparable output current were coupled to achieve a power density equal to the sum of $p$ - and n-type half-cells, indicating the low internal resistance of electrode materials. We then demonstrated the scalability of the system, fabricating an array with 18 pairs of $\mathrm{p}$-n series devices able to charge capacitors to above $0.3 \mathrm{~V}$. Finally, we prototyped the $\mathrm{p}-\mathrm{n}$ array into a watch-strap style-integrated device, which efficiently converted body heat to electrical energy and provided continuous power to a green light emitting diode (LED).

\section{Results and Discussions}

\subsection{Developing an n-type gel electrolyte}

An n-type-PVA- $\mathrm{FeCl}_{2 / 3}$ gel electrolyte was prepared by chemically cross-linking PVA in the presence of $\mathrm{FeCl}_{2 / 3}$. To achieve gel formation, $1 \mathrm{M} \mathrm{FeCl}_{2 / 3}$ was dissolved in 5 wt.\% PVA (85-124 kDa) in $\mathrm{H}_{2} \mathrm{O}$, forming a relatively low-viscosity solution. Glutaraldehyde (GA) diluted solution (5 wt.\%) was then added, accompanied by rapid and vigorous stirring. The mixed solution was immediately poured into a mould or injected into the thermo-electrochemical cell. In the weakly acidic $\mathrm{Fe}^{2+} / \mathrm{Fe}^{3+}$ solution, the cross-linked PVA hydrogel was formed via the reaction between the hydroxyl groups of PVA and the aldehyde groups in GA (forming acetal or hemiacetal links between PVA polymer chain). ${ }^{\left[{ }^{35]}\right.}$ After 0.5 hour, the cross-linked gel electrolyte was able to be removed from the mould (for physical characterization) or directly used as an electrolyte in thermo-cells.

This article is protected by copyright. All rights reserved. 


\section{WILEY-VCH}

The as-prepared n-type gel electrolyte is highly flexible and stretchable (Figure 2a), and can maintain its shape after being bent, twisted, or even stretched to twice its original length while being twisted over 360 degrees. After repeated cyclic stretching to $100 \%$ strain (Figure $\mathbf{2 b}$ ), the gel electrolyte shows less than $10 \%$ plastic deformation (over 60 cycles), indicating its excellent elasticity and cyclic stability. ${ }^{[36]}$ These robust mechanical properties (flexibility, elasticity, and toughness) emphasizes the potential of this gel electrolyte in wearable applications and even epidermal devices. ${ }^{[37]}$ Meanwhile, this gel electrolyte could be potentially adapted to fit future stretchable thermo-cells, which is not the subject of this work but merit considerable further study for wearable devices. ${ }^{[37]}$ The effect of the molecular weight and concentration of PVA, as well as the concentration of $\mathrm{FeCl}_{2 / 3}$ and acidity of the electrolyte were investigated to achieve optimal parameters with respect to mechanical properties, ionic conductivity, and thermo-cell performance (See Supplementary Information text, Figure S1-S5). Meahwhile, extended thermo-electrochemical performance over 4 days were test to show the excellent thermo-electrochemical stability of the gel electrolyte (See Supplementary Information text, Figure S5d). Below we discuss the performance of the optimized n-type gel electrolyte

The electrochemistry of the as-prepared PVA- $\mathrm{FeCl}_{2 / 3}$ gel electrolyte (5wt.\% PVA and $1 \mathrm{M} \mathrm{FeCl} 2 / 3$ concentration) was evaluated and compared to a $1 \mathrm{M} \mathrm{FeCl}_{2 / 3}$ aqueous electrolyte (Figure $\mathbf{2 c}$-d) using a thin-film platinum electrode (ED-SE1-Pt, Micrux) where Pt works as both the reference and counter electrodes. The gel electrolyte displayed an almost identical cyclic voltammetry (CV) curve (scan rate $\left.=50 \mathrm{mV} \mathrm{s}^{-1}\right)$ to the liquid electrolyte, with a slightly smaller separation between the reduction and oxidation peaks $\left(\Delta E_{p}\right)(216 \mathrm{mV} v s .257 \mathrm{mV})$. The $\Delta \mathrm{E}_{\mathrm{p}}$ relates to the reversibility of the redox couples in gel and liquid electrolyte, indicating that the electro-activity of redox couples has not been affected

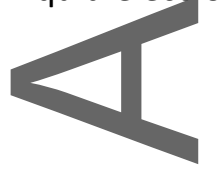

This article is protected by copyright. All rights reserved. 


\section{WILEY-VCH}

by the presence of the PVA polymer host. The same diffusion limited redox behavior was observed in both gel and liquid electrolytes, reflected by the linear relationship between the square root of scan rate and the peak current density (Figure S1d and Figure S2d). ${ }^{[23,38]}$ The high frequency domain of electrochemical impedance spectra (EIS) of both gel and liquid electrolytes shows a small equivalent series resistance (ESR) ( $50 \Omega$, derived from the intercept of the real part of impedance with the $x$ axis), indicating that the gel electrolyte exhibits a comparably high ionic conductivity to the liquid electrolyte. ${ }^{[36,39]}$ As expected, a larger electron transfer resistance $\left(R_{E T}\right.$, defined by the size of the semicircle at high frequency domain) was observed in the gel polymer electrolyte (90 $\Omega$ ) than in the liquid electrolyte $(50 \Omega) \cdot{ }^{[36,39]}$ However, this charge transfer resistance was still small enough to enable rapid charge transport and enable rapid redox reactions, as evidenced by the CV results. Therefore, the redox reaction of the as-prepared $\mathrm{PVA}-\mathrm{FeCl}_{2 / 3}$ gel electrolyte is quasi-reversible and displays similar electrochemical performance compared with the liquid electrolyte. ${ }^{[38]}$

Given the promising CV and EIS results, the thermo-electrochemical (TEC) performance of these gel electrolytes was further investigated. As discussed in the experimental section, sputter-coated platinum was used for the electrodes with a $2 \mathrm{~mm}$ inter-electrode spacing. While maintaining the temperature of the hot electrode $\left(T_{H}\right)$ at $35{ }^{\circ} \mathrm{C}$ and gradually decreasing the cold electrode temperature $\left(T_{C}\right)$ from $30^{\circ} \mathrm{C}$ to $15^{\circ} \mathrm{C}$, the output voltage was observed to change linearly with $\Delta T$ (Figure S3), giving a Seebeck coefficient of $+0.78 \mathrm{mV} \mathrm{K}^{-1}$. The Seebeck coefficient was slightly smaller compared to that of an aqueous electrolyte system $\left(+0.81 \mathrm{mV} \mathrm{K}^{-1}\right)$. This difference is hypothesized to arise from the higher thermal conductivity of cross-linked polymer gels (PVA-FeCl $2 / 3$ gel: $1.02 \mathrm{~W} \mathrm{~m}^{-1}$ $\mathrm{K}^{-1}$, PVA gel: $1.01 \mathrm{~W} \mathrm{~m}^{-1} \mathrm{~K}^{-1}$ ) compared to water-based systems (PVA aqueous solution: $0.588 \mathrm{~W} \mathrm{~m}^{-1}$ $\mathrm{K}^{-1}$, water: $0.60 \mathrm{~W} \mathrm{~m}^{-1} \mathrm{~K}^{-1}$, the value of $\mathrm{PVA}-\mathrm{FeCl}_{2 / 3}$ solution and $\mathrm{FeCl}_{2 / 3}$ aqueous solution were not

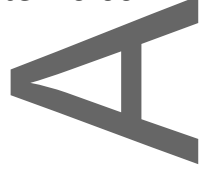

This article is protected by copyright. All rights reserved. 


\section{WILEY-VCH}

measured to avoid the corrosion of the metal thermal sensor by acidic solution). ${ }^{[40]}$ Since the use of chemical cross-linking clearly demonstrates significant advantages such as strong mechanical strength and high concentration of redox couples, the slight decrease in Seebeck coefficient is acceptable. The TEC shows a simple linear current - voltage and parabolic power - voltage relationship, with a short circuit current density $\left(\mathrm{J}_{\mathrm{SC}}\right)$ of $8.2 \mathrm{~A} \mathrm{~m}^{-2}$ and maximum power density $\left(\mathrm{P}_{\mathrm{MAX}}\right)$ of $17.1 \mathrm{~mW} \mathrm{~m}^{-2}$ (Figure $\left.2 \mathrm{e}\right)$. The smaller $\mathrm{J}_{\mathrm{sc}}\left(8.2 \mathrm{~A} \mathrm{~m}^{-2}\right)$ of the gel electrolyte compared to the liquid electrolyte $\left(12 \mathrm{~A} \mathrm{~m}^{-2}\right.$ ) arises from the lower $R_{E T}$ (Figure $2 d$ ). The result shows the $n$-type electrolyte performance is comparable to reported p-type electrolytes when sputter-coated Pt was used as electrode (Figure $\mathbf{5 6}$ ), demonstrating the potential for development of $p-n$ arrays.

\subsection{Electrode optimization for $p$ - and $n$ - type cells}

Once the electrolyte had been fully optimized, development of advanced electrodes tailored to match our gel electrolytes was undertaken to achieve the maximum possible device performance. To enable intimate contact between the electrode materials and the flexible substrate, a simple drop-casting method was used to prepare electrodes on Pt-coated PI tape (Figure 3a). This method eliminates the need for any additional steps to transfer the free-standing electrodes onto the target substrate. ${ }^{[20,21]}$ For a homogenous drop-casting dispersion, a water-dispersible and commercially available conducting polymer PEDOT/PSS was used as a dispersing agent for carbon-based materials (i.e. EFG and CNTS). Uniform PEDOT/PSS-EFG/CNT dispersions could be formed when the ratio of PEDOT/PSS was larger than 25 wt.\% in the composite. Diethylene glycol (DEG), which is a commonly employed secondary dopant for PEDOT/PSS used to boost the electrical conductivity, was added to all samples. ${ }^{[41]}$ In addition, a thin layer of PEDOT/PSS $\left(0.3 \mathrm{mg} \mathrm{cm}^{-2}\right)$ was prepared as a soft and adhesive layer on the flexible substrate, prior to the PEDOT/PSS-EFG/CNT film drop-casting process.

This article is protected by copyright. All rights reserved. 


\section{WILEY-VCH}

This additional layer serves to prevent delamination of the composite film from the substrate during the heat evaporation process (Figure S8) or during bending (Figure 3a). $\mathrm{A} \mathrm{CO}_{2}$ laser cutter was used to etch the electrode materials creating $\approx 100 \mu \mathrm{m}$ wide channels (Figure S7) with a depth equal to the thickness of the film electrode. This process was used to increase the surface area and increase diffusion of the redox species through the electrode films. The as-prepared electrodes (Figure 3a, b) on PI tape were-assembled into a TEC device, followed by injection of the gel electrolyte ( $p$-type: $\mathrm{CMC} \mathrm{K}_{3 / 4} \mathrm{Fe}(\mathrm{CN})_{6}$, n-type: $\mathrm{PVA}-\mathrm{FeCl}_{2 / 3}$, respectively) into the device. TEC performance of the film electrodes and the full TEC device was evaluated while applying a $\Delta T=10^{\circ} \mathrm{C}$ between the two electrodes $\left(T_{H}=35^{\circ} \mathrm{C}\right.$ and $\left.T_{C}=25^{\circ} \mathrm{C}\right)$. Step-by-step optimization of the electrode composition and film thickness (See Supplementary Information text and Figure S9 and Figure S10) was performed to attain high performance electrodes.

Figure 3c shows the optimized performance of the $p$-type electrode (laser-etched PEDOT/PSS$\mathrm{EFG} / \mathrm{CNT}$ ), which has improved thermo-electrochemical performance compared with the PEDOT/PSS-EFG/CNT film and pristine platinum electrodes in terms of open circuit voltage (12.2 mV versus $11.5 \mathrm{mV}$ and $10.2 \mathrm{mV}$, demonstrating an improvement in 'observed $\Delta \mathrm{T}^{\prime}$ ), short circuit current density (18.5 $\mathrm{A} \mathrm{m}^{-2}$ versus $19.5 \mathrm{~A} \mathrm{~m}^{-2}$ and $\left.10.2 \mathrm{~A} \mathrm{~m}^{-2}\right)$, and maximum power density $\left(72.9 \mathrm{~mW} \mathrm{~m}^{-2}\right.$ versus $60.7 \mathrm{~mW} \mathrm{~m}^{-2}$ and $32.9 \mathrm{~mW} \mathrm{~m}^{-2}$ ) at $\Delta \mathrm{T}=10{ }^{\circ} \mathrm{C}$. A high $\mathrm{P}_{\mathrm{MAX}} / \Delta \mathrm{T}^{2}$ value of $0.73 \mathrm{~mW} \mathrm{~K}^{-2} \mathrm{~m}^{-2}$ (comparable to literature values for high-performance electrodes) ${ }^{[22]}$ was calculated to account for the difference in $\Delta \mathrm{T}$ of thermo-cells run at different operating temperatures. We ascribe the improved performance to the high-quality EFG, the open and porous layer-by-layer structure (Figure 3b), and the laser-etched channels enabling a high ion-accessible surface area with high electrical conductivity. The optimal p-type electrode composition of PEDOT/PSS-EFG/CNT film electrode

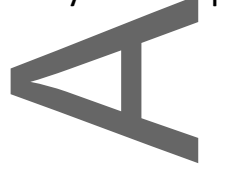

This article is protected by copyright. All rights reserved. 


\section{WILEY-VCH}

outperforms all others in terms of current density and power density. This performance arises due to the synergistic combination of EFG and CNTs, which form a hierarchically porous, high surface area network with outstanding electrical conductivity and known electrocatalytic behavior for the $\left[\mathrm{Fe}(\mathrm{CN})_{6}\right]^{3-44}$ redox couple. ${ }^{[18,21,42-44]}$ However, the thick PEDOT/PSS-EFG/CNT film electrode also exhibits increased thermal resistance, resulting in a relatively low open circuit voltage of $10.2 \mathrm{mV}$. To solve this problem, the additional laser-etching process was applied to the film electrode, which enabled the direct exposure of thermally conductive Pt to the gel polymer electrolyte. The key benefit of this additional process was that the effective temperature difference between the cold and hot electrode/electrolyte interface was increased, leading to an enhancement in the open circuit voltage compared with the un-etched samples (from $10.2 \mathrm{mV}$ to $12.2 \mathrm{mV}$ ) without sacrificing the output current. An improved $\mathrm{P}_{\text {MAX }}$ was thus achieved from $60.7 \mathrm{~mW} \mathrm{~m}^{-2}$ to $72.9 \mathrm{~mW} \mathrm{~m}^{-2}$.

In terms of the long-term power output of the optimized device, the short circuit current $\left(\mathrm{I}_{\mathrm{sc}}\right)$ over time was measured (Figure S11a) and the long-term $P_{M A X} / \Delta T^{2}\left(P_{M A X}=1 / 4 \times I_{S C} \times V_{O c V}\right)$ was calculated. The high current-output and $\mathrm{P}_{\mathrm{MAX}} / \Delta \mathrm{T}^{2}$ decreased initially before stabilizing after 30 min of thermocell discharge. This decrease is a limitation of all gel-related thermo-cells and arises from the low diffusion rate of redox couples in gel electrolyte. Due to the higher driving potential for ion diffusion, the laser-etched PEDOT/PSS-EFG/CNT maintains a higher long-term current density $\left(1.15 \mathrm{~A} \mathrm{~m}^{-2}\right.$ versus $\left.1.0 \mathrm{~A} \mathrm{~m}^{-2}\right)$ and $\mathrm{P}_{\text {MAX }} / \Delta \mathrm{T}^{2}\left(0.0351 \mathrm{~mW} \mathrm{~K}^{-2} \mathrm{~m}^{-2}\right.$ versus $\left.0.0255 \mathrm{~mW} \mathrm{~K}^{-2} \mathrm{~m}^{-2}\right)$ compared to an unetched electrode. The $38 \%$ improvement in $\mathrm{P}_{\mathrm{MAX}} / \Delta \mathrm{T}^{2}$ indicates the efficacy of the laser-etching process. The long-term $\mathrm{P}_{\mathrm{MAX}} / \Delta \mathrm{T}^{2}$ of our optimized device is comparable with reported gel electrolyte systems. ${ }^{[19,23,25,45]}$

This article is protected by copyright. All rights reserved. 


\section{WILEY-VCH}

Once the p-type cell electrode was optimized, electrodes suitable for use with our developed PVA$\mathrm{FeCl}_{2 / 3}$ electrolytes (n-type) were investigated, with a target of reaching comparable performance to the p-type-configuration. Surprisingly, it was found that the single component film electrode of PEDOT/PSS exhibited superior performance surpassing all the other studied carbon-based materials including PEDOT/PSS-EFG, PEDOT/PSS-CNT, and PEDOT/PSS-EFG/CNT (Figure S10a). This outstanding performance may have arisen from the unique electrocatalytic behavior of PEDOT/PSS for the $\mathrm{Fe}^{2+} / \mathrm{Fe}^{3+}$ redox couple. As reported in the literature, excess PSS in PEDOT/PSS can enhance cation transport through the polymer electrode with a particularly high affinity for multivalent cations such as $\mathrm{Fe}^{2+}$ and $\mathrm{Fe}^{3+}$. Due to their strong electrostatic attractions, $\mathrm{Fe}^{2+}$ and $\mathrm{Fe}^{3+}$ ions can easily absorb onto the electrode surface of PEDOT/PSS film electrodes. ${ }^{[46,47]}$ Along with the high electrical conductivity and abundant micro-sized pores in the electrode film (Figure 3d), fast ion diffusion and electron transfer are predicted in the PEDOT/PSS electrodes. ${ }^{[41]}$ The performance of PEDOT/PSS was further improved by increasing the mass loading to $4 \mathrm{mg} \mathrm{cm}^{-2}$ (Figure S1Ob) and adding an additional laser-etching (Figure 3e) process for enhanced output current and output voltage. A full summary of the tested electrodes and their relative performance is shown in Table S1.

After optimization, the laser-etched PEDOT/PSS electrodes delivered a much higher TEC performance than PEDOT/PSS film and pure Pt electrodes (Figure 3e), including the open circuit voltage (8.5 mV versus $6.7 \mathrm{mV}$ and $8.0 \mathrm{mV})$, short circuit current density (17.4 $\mathrm{A} \mathrm{m}^{-2}$ versus $14.4 \mathrm{~A} \mathrm{~m}^{-2}$ and $\left.10.2 \mathrm{~A} \mathrm{~m}^{-2}\right)$, and maximum power density (38.3 $\mathrm{mW} \mathrm{m}^{-2}$ versus $24.3 \mathrm{~mW} \mathrm{~m}^{-2}$ and $\left.20.6 \mathrm{~mW} \mathrm{~m}^{-2}\right)$. Notably, this is the first time that the performance of an $\mathrm{n}$-type device has been optimized in combination with conducting polymer-based electrode materials, which exhibit comparable performance with carbon-based materials in aqueous electrolyte. ${ }^{[31,48]}$ In addition, the ease in

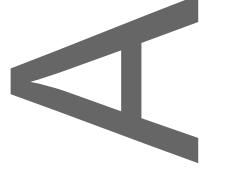

This article is protected by copyright. All rights reserved. 


\section{WILEY-VCH}

dispersion preparation and the processability of PEDOT/PSS has greatly simplified the film preparation process compared to the alternative carbon-based electrodes. ${ }^{[31,48]}$ In terms of longterm performance, the laser-etched process shows the same benefit in n-type devices as in p-type device (Figure S11b). There is a $25 \%$ improvement in current density $\left(1.5 \mathrm{~A} \mathrm{~m}^{-2}\right.$ versus $1.2 \mathrm{~A} \mathrm{~m}^{-2}$ ) and $60 \%$ increase in $\mathrm{P}_{\mathrm{MAX}} / \Delta \mathrm{T}^{2}\left(0.0322 \mathrm{~mW} \mathrm{~K}^{-2} \mathrm{~m}^{-2}\right.$ versus $\left.0.0201 \mathrm{~mW} \mathrm{~K}^{-2} \mathrm{~m}^{-2}\right)$ when comparing the laseretched PEDOT/PSS device to the unetched device. The long-term $\mathrm{P}_{\mathrm{MAX}} / \Delta \mathrm{T}^{2}$ is also comparable with the literature reported gel electrolytes. ${ }^{[19,34,49]}$ In addition, it is found that the output current of this optimized n-type device is comparable with our optimized p-type device in terms of both the initial value (17.5 $\mathrm{A} \mathrm{m}^{-2}$ versus $18.5 \mathrm{~A} \mathrm{~m}^{-2}$ ) and the long-term value $\left(1.5 \mathrm{~A} \mathrm{~m}^{-2}\right.$ versus $1.15 \mathrm{~A} \mathrm{~m}^{-2}$ ), indicating the potential for effective $p-n$ in-series connection.

\subsection{Pairing the $p-n$ cells}

As mentioned aboye, the selection criteria for efficient series connection between $\mathrm{p}$-type and n-type cells is the comparable output current between each device, which has been achieved herein via the optimization of both electrolyte and electrode for both p-type and n-type devices. Here, a typical pair of p-n cells were fabricated and examined (Figure 4a), where the optimized electrodes of laseretched PEDOT/PSS and PEDOT/PSS-EFG/CNT and electrolytes of PVA-FeCl $2 / 3\left(1 \mathrm{M} \mathrm{FeCl}_{2 / 3}\right) / 0.08 \mathrm{M}$ $\mathrm{HCl}$ and $\mathrm{CMC}_{-K_{3 / 4}} \mathrm{Fe}(\mathrm{CN})_{6}\left[0.4 \mathrm{M} \mathrm{K}_{3 / 4} \mathrm{Fe}(\mathrm{CN})_{6}\right]$ were used in n-type and p-type cells, respectively. Sputter-coated Pt acts both as the current collector and the connection between adjacent devices. As expected, the voltage of the $p-n$ combined cell was approximately equal to the sum of the absolutevoltage of both $\mathrm{p}$-type and $\mathrm{n}$-type devices, and increased linearly with $\Delta T$ (Figure $4 \mathbf{b}$ ). Thus, the effective Seebeck coefficient of the $\mathrm{p}-\mathrm{n}$ cell was $1.96 \mathrm{mV} \mathrm{K} \mathrm{K}^{-1}$, approaching the sum of the absolute value of each component $\left(-1.17 \mathrm{mV} \mathrm{K}^{-1}\right.$ for $\mathrm{p}$-type device, and $+0.85 \mathrm{mV} \mathrm{K}^{-1}$ for n-type

This article is protected by copyright. All rights reserved. 


\section{WILEY-VCH}

device). Further, the initial and the long-term short-circuit current of the $p$-n cell was nearly the same as the individual $p$-type and $n$-type devices at a $\Delta T=10 \mathrm{~K}$, indicating the efficient matching and low resistance of the electrical connections between the devices (Figure $\mathbf{4 b}$ and Figure S11c). The $p$ $\mathrm{n}$ cell performance at various $\Delta \mathrm{T}\left(5^{\sim 20} \mathrm{~K}\right)$ was examined, yielding linear $\mathrm{V} v s \mathrm{I}$ and parabolic $\mathrm{P} v s \mathrm{~V}$ relationships at all temperature differences. These results indicate that the $p-n$ cell was stable at a variety of temperatures.

\subsection{Prototyping multiple p-n cells}

A prototype device of thermo-cell arrays containing multiple $p$-n cells connected in series was fabricated ( 6 pairs of $p$-n cells in Figure $5 \mathbf{a}$, and $3 \times 6$ pairs of $p$-n cells in Figure $5 \mathbf{b}$ ) and the scalability (with respect to the number of $\mathrm{p}-\mathrm{n}$ units in the device) was probed. With a $\Delta \mathrm{T}$ of $10 \mathrm{~K}$, the voltage increases linearly from $20.1 \mathrm{mV}$ to $351 \mathrm{mV}$ with increasing number of $\mathrm{p}$-n cell pairs from 1 to 18 . We also note that the current output (blue curve, Figure $\mathbf{5 c}$ ) decreased when the number of $p-n$ pairs increased due to an increasing amount of electrical resistance between cell connections. As a result, the power output reaches a plateau when there are 18 pairs of $p$-n cells. Due to the high energy output (up to $38.3 \mu \mathrm{W}$ ) from the 18 pair configuration, the $p$-n cell arrays ( $\Delta T=10 \mathrm{~K}$ ) were able to charge not only a capacitance dielectric capacitor $(C=10 \mathrm{mF}$ ), but also electrochemical supercapacitors (C $=47 \mathrm{mF}, 100 \mathrm{mF}, 470 \mathrm{mF}$ ) to more than $300 \mathrm{mV}$. The charge rate for $10 \mathrm{mF}, 47$ $\mathrm{mF}$ and $100 \mathrm{mF}$ supercapacitors is high and charging could be achieved in a few minutes. One problem with using the gel electrolytes in-series is the decrease in long-term performance, which resulted in a decrease in the charging rate of supercapacitors after extended durations, especially for supercapacitors with large capacitances (i.e. $470 \mathrm{mF}$ ). This limitation of long-term performance is expected to be solved in the future when advanced gel electrolytes are developed, leading to greatly

This article is protected by copyright. All rights reserved. 


\section{WILEY-VCH}

improved long-term charging rates with our advanced electrode and p-n series system. In addition, we also claim that this is the first time that thermo-cells with gel electrolyte harvesting low-grade heat have been demonstrated to charge high energy density supercapacitors, and subsequently power a LED.

\subsection{Flexible and wearable $p-n$ cells}

To harvest body heat, a flexible thermo-cell, which can conform to a curved surface is required. However, bending layered devices to a high degree of curvature while maintaining performance is challenging, even when the individual components are highly flexible, as the top electrodes (air-side) always bear larger deformation relative to the bottom electrodes (skin-side). To address this problem, we designed a thermo-cell with a watch-strap shape, where the bottom electrodes between $\mathrm{p}$-n cells were electrically connected on one flexible substrate (i.e. polyimide tape) but the top electrodes were not connected and separated on different substrates (Figure 6a). In this case, the top electrodes of each $\mathrm{p}$-n pair could move freely, while the bottom electrodes conformed to the high curvature encountered with anatomical parts. Meanwhile, flexible and thermally conductive aluminum foil was attached outside of the thermo-cell device in order to maintain uniform heat transfer through electrodes. As a demonstration, we have attached 5 straps of thermo-cell arrays (6 p-n pairs) on a wrist (Figure 6 b). These 30 p-n pairs can charge a $470 \mathrm{mF}$ supercapacitor during longterm wear. The charged supercapacitor was able to light a green LED with voltage booster (Figure $\mathbf{6 b}$ and Supporting Infomation Movie S1). This demonstrates the practical utility of our thermo-cells to power a range of wearable and portable electronics from low-grade body heat.

\section{Conclusion}

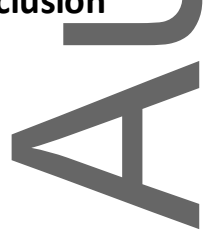

This article is protected by copyright. All rights reserved. 


\section{WILEY-VCH}

In summary, we have developed high performance p-type and n-type flexible thermo-cells through systematic investigation of both electrodes and gel electrolytes, which are of vital importance in establishing effectively paired $p$-n cells. We have shown that an optimized $n$-type PVA-FeCl $2 / 3$ gel electrolyte prepared by an in situ chemical cross-linking exhibits comparable performance to the state-of-the-art $\mathrm{p}$-type electrolyte $\left.\left[\mathrm{CMC}-\mathrm{K}_{3 / 4} \mathrm{Fe}(\mathrm{CN})_{6}\right)\right]$. Then, we developed and optimized both $\mathrm{p}$ type and n-type electrodes with a flexible and porous structure. PEDOT/PSS and PEDOT/PSSEFG/CNT electrodes showed excellent and comparable performance for $n$-type and $p$-type cells respectively, enabling the devices to be coupled together efficiently. We also successfully matched these thermocells by connecting multiple $\mathrm{p}$-n cells in series, achieving an increased voltage to $0.34 \mathrm{~V}$ at $\Delta T=10 \mathrm{~K}$ and $\mathrm{a}$ current large enough to charge supercapacitors. Furthermore, the demonstration of a flexible watch-strap shaped thermo-cell that could harvest body heat, charge supercapacitors and light a green LED, highlighted the potential of these devices in real applications. We believe this systematic investigation and optimization of electrode, electrolyte, and device architectures introduced here has great significance for the realization of body heat harvesting and application in real self-powered wearable electronics.

\section{Experimental Section}

Materials. The PEDOT/PSS used was the Orgacon ${ }^{\mathrm{TM}}$ DRY product from Agfa Company. Multi wall carbon nanotubes (MWCNT) were obtained from Carbon Nanotube Plus. Edge functionalized graphene (EFG) was prepared in our laboratories. ${ }^{[50]}$ Diethylene glycol (DEG), polyvinyl alcohol (PVA, Mw: 31,000 50,000, 85,000 - 124,000, 146,000 - 186,000 Sigma 363162), carboxymethylcellulose sodium (CMC, Mw: 250,000), iron (II) chloride tetrahydrate $\left(\mathrm{FeCl}_{2} \cdot 4 \mathrm{H}_{2} \mathrm{O}\right)$, iron (III)

This article is protected by copyright. All rights reserved. 


\section{WILEY-VCH}

chloride $\left(\mathrm{FeCl}_{3}\right)$, potassium ferricyanide $\left[\mathrm{K}_{3} \mathrm{Fe}(\mathrm{CN})_{6}\right]$, potassium hexacyanoferrate

(II) $\left[\mathrm{K}_{4} \mathrm{Fe}(\mathrm{CN})_{6} \cdot 3 \mathrm{H}_{2} \mathrm{O}\right]$, glutaraldehyde solution $\left(25 \mathrm{wt} . \%\right.$ in $\left.\mathrm{H}_{2} \mathrm{O}\right)$ were purchased from Sigma-Aldrich.

PVA- $\mathrm{FeCl}_{2 / 3}$ gel electrolyte solution: $\mathrm{PVA}-\mathrm{FeCl}_{2 / 3}$ solutions were prepared by dissolving $\mathrm{FeCl}_{2} \cdot 4 \mathrm{H}_{2} \mathrm{O}$ and

a

$\mathrm{FeCl}_{3}$ powder into pre-prepared PVA aqueous solutions (with magnetic stirring) for $1 \mathrm{~h}$. PVA solutions of 3 wt.\%, 5 wt.\%, 8 wt.\% and 10 wt.\% were used, with $0.1 \mathrm{M}, 0.2 \mathrm{M}, 0.5 \mathrm{M}, 1 \mathrm{M}$, or $2 \mathrm{M}$ $\mathrm{FeCl}_{2 / 3}$. The chemical cross-linker of diluted $\mathrm{GA}\left(5 \mathrm{wt} . \%\right.$ in $\mathrm{H}_{2} \mathrm{O}$, mass ratio of PVA:GA $=40: 1$ ) was then dropped into the mixed solution with vigorous magnetic stirring for $30 \mathrm{~s}$. Subsequently, the PVA-FeCl $2 / 3-$ GA solution was immediately poured into a PDMS mould or injected into the assembled thermo-electrochemical device. Finally, the solid-state gel electrolyte was formed after cross-linking at room temperature for $1 \mathrm{~h}$, which was then either peeled off for electrochemical and mechanical testing or directly used as electrolyte in the thermo-electrochemical device. For performance enhancement, $\mathrm{HCl}$ with the final concentration varying from 0.02 to $0.3 \mathrm{M}$ was added into the PVA$\mathrm{FeCl}_{2 / 3}$ solutions before the addition of chemical cross-linker (GA).

$\mathrm{CMC}-\mathrm{K}_{3 / 4} \mathrm{Fe}(\mathrm{CN})_{6}$ gel electrolyte: $\mathrm{CMC}-\mathrm{K}_{3 / 4} \mathrm{Fe}(\mathrm{CN})_{6}$ gel electrolyte was prepared following the method described by Russo et al., ${ }^{[24]}$ whereby the appropriate amount of $\mathrm{CMC}$ powder was added to $0.4 \mathrm{M}$ $\mathrm{K}_{3} \mathrm{Fe}(\mathrm{CN})_{6} / \mathrm{K}_{4} \mathrm{Fe}(\mathrm{CN})_{6}$ aqueous solution with magnetic stirring overnight. The prepared viscous CMC$\mathrm{K}_{3 / 4} \mathrm{Fe}(\mathrm{CN})_{6}$ solution was stirred for at least $30 \mathrm{~min}$ prior to being injected into thermoelectrochemical devices for performance testing.

Preparation of flexible film: A ball milling method was used to prepare PEDOT/PSS-based inks. Firstly, PEDOT/PSS pellets with different mass loadings of MWCNT and EFG were mixed by ball milling at $1200 \mathrm{rpm}$ for $10 \mathrm{~min}$. This ball milling process works on the principle of impact and attrition when This article is protected by copyright. All rights reserved. 


\section{WILEY-VCH}

the balls drop from near the top of the shell. After ball milling, the MWCNT and EFG powers are bound to the surface of PEDOT: PSS and this mixture could be well dispersed in water by magnetic stirring overnight and bath sonicating for $30 \mathrm{~min}$. DEG (weight ratio of DEG: PEDOT/PSS=1:1.86) was added to the aqueous dispersion prior to stirring. The PEDOT/PSS ink was prepared by directly dispersing the PEDOT/PSS in water with the addition of DEG. PEDOT/PSS, PEDOT/PSS-EFG, PEDOT/PSS-CNT,PEDOT/PSS-EFG/CNT films were prepared by bar coating a thin layer of the mixed dispersion on $\mathrm{Pt}$ coated-PI tape, where the sputter coated $100 \mathrm{~nm}$ platinum functions as current collector. The films were dried at room temperature overnight, followed by heating in an oven at 70 oC for $2 \mathrm{~h}$ to fully remove DEG.

Laser-etching of film electrode: The laser-etching step was conducted using a $10.6 \mu \mathrm{m} \mathrm{CO}_{2}$ laser cutting system (Universal PLS6MW Multi-Wavelength Laser Platform, $30 \mathrm{~W}$, spot size of $\approx 25 \mu \mathrm{m}$ ) under ambient conditions. It was conducted using a vector mode with the laser power set as $0.1 \%$ and the speed fixed at $2 \%$. The pulses per inch was set at 500 .

Device Assembly of series-connected thermo-electrochemical cells: Thermo-cell devices containing a series of interconnected p-type and n-type devices were fabricated. These devices consist of a lasercut acrylic frame (Figure 5a, with each cell size $[I \times w \times t]$ being $0.5 \times 2 \times 0.2 \mathrm{~cm}$ ), drop-casted and laser-etched film electrodes on sputter coated platinum, and a PI tape substrate. Firstly, $100 \mathrm{~nm} \mathrm{Pt}$ was sputter coated on PI tape substrate (fixed on aluminum plate) with designed patterns, which act as both current collector and connection wires between single devices. Then, film electrodes were selectively drop-casted on the platinum coated electrode area $(0.5 \times 2 \mathrm{~cm})$ and laser-etched via the laser cutting system (Figure 5a). The acrylic frame was then sandwiched between two of the electrode-Pt coated PI and sealed by epoxy resin glue. Finally, electrolyte precursors were injected

This article is protected by copyright. All rights reserved. 


\section{WILEY-VCH}

into the cells through pre-prepared holes on the frame to form interconnected thermo-cells. Flexible series-connected, thermo-cells (Figure 6) were prepared in the same precursor, but replacing the laser-cut acrylic frame with a 3D printed flexible PDMS frame. To enable the production of flexible devices, aluminum foilinstead of aluminum plates was used as a thermal conductor.

Electrochemical characterizations of polymer gel electrolyte: The electrochemical performance of the gel electrolytes was tested using thin-film platinum electrodes (ED-SE1-Pt, Micrux) equipped with All-In-One Platform, in which the working (diameter $=1 \mathrm{~mm}$ ), reference, and counter electrodes were screen printed platinum. $400 \mu \mathrm{L}$ of the gel electrolyte precursor was dropped into the cell and allowed to gel for $1 \mathrm{~h}$ prior to testing. The CV measurements were performed using a VSP electrochemical workstation (Bio-Logic, France) and EC-Lab software. Electrochemical impedance was obtained by employing a frequency range of $1 \mathrm{MHz}$ to $0.01 \mathrm{~Hz}$ and an $\mathrm{AC}$ amplitude of $10 \mathrm{mV}$ at open circuitvoltage.

Thermo-electrochemical measurements: The thermo-electrochemical performance of the gel electrolytes was tested in a thermo-cell device with a home-made temperature controller (Figure S12). The temperature controller can moderate the aluminium plate to a specific temperature by heating or cooling via a Peltier device, which was controlled by a microcontroller (TEC-1091, Meerstetter Engineering) together with the TEC Service Software. The thermo-cell consists of two electrodes (electrode materials coated on $100 \mathrm{~nm}$ Pt coated PI tape) and an acrylic frame (with two holes for electrolyte injection) to fix the size of the cell to $1 \mathrm{~cm} \times 1 \mathrm{~cm}$ and distance between the two electrodes of $2 \mathrm{~mm}$. The electrolyte precursor was injected into the cell and allowed to gel for $1 \mathrm{~h}$ prior to testing. During testing, the hot side was kept at $35{ }^{\circ} \mathrm{C}$ simulating body heat temperature, whereas the code side was varied from $15{ }^{\circ} \mathrm{C}$ to $35^{\circ} \mathrm{C}$ analogous to the outside environment. The

This article is protected by copyright. All rights reserved. 


\section{WILEY-VCH}

open-circuit voltage $\left(\mathrm{V}_{\text {oc }}\right)$ and current-voltage characterization of the cells was measured using a VSP electrochemical workstation (Bio-Logic, France).

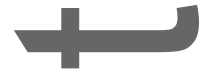

Physical Characterizations: Patterns of laser-cut microdevices were observed by optical microscopy (Leica DM6000 upright microscope). The cross-section morphology of drop-cast and laser-cut films was investigated from a JEOL JSM-7500FA field emission SEM with the accelerating voltage set at 5.0 $\mathrm{kV}$ and the emission current at $10 \mathrm{~mA}$. The tensile tests of the hydrogels (length $=50 \mathrm{~mm}$, width $=10$ $\mathrm{mm}$, and thickness $=2 \mathrm{~mm}$ ) were carried out using Shimadzu EZ mechanical tester (Shimadzu, Kyoto, Japan) with aload of $10 \mathrm{~N}$ and tensile speed of $25 \mathrm{~mm} \mathrm{~min}^{-1}$ at room temperature.

\section{Supporting Information}

Supporting Information is available from the Wiley Online Library or from the author.

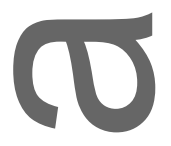

\section{Acknowledgements}

Funding from the Australian Research Council (ARC) Centre of Excellence Scheme (DP170102320 and CE 140100012) is gratefully acknowledged. The authors would like to thank The Materials Node of the Australian National Fabrication Facility for materials and the printing process, and the University of Wollongong (UOW) Electron Microscopy Centre for equipment use.

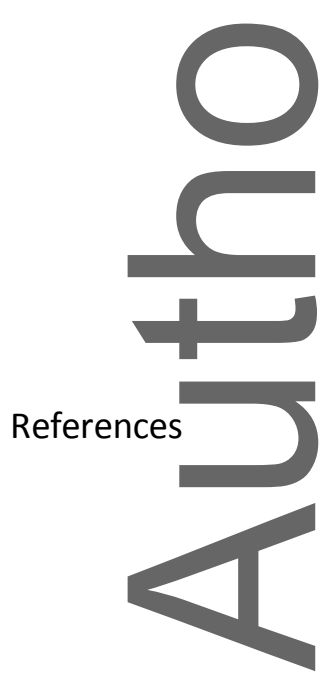

Received: ((will be filled in by the editorial staff))

Revised: ((will be filled in by the editorial staff)) Published online: ((will be filled in by the editorial staff))

This article is protected by copyright. All rights reserved. 


\section{WILEY-VCH}

[1] Z. Lou, L. Li, L. Wang, G. Shen, Recent Progress of Self-Powered Sensing Systems for Wearable Electronics. Small 2017, 13, 1701791.

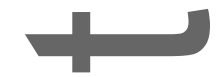

[2] C. Shi, Qiongfeng, Dong, Bowei, He, Tianyiyi, Zhongda Sun, Zhu, Jianxiong, Zhang, Zixuan, Lee, InfoMat 2020,1.

[3] Y. Xu, Y.Zhao, J. Ren, Y. Zhang, H. Peng, Angew. Chemie 2016, 128, 8111.

[4] D. Kim, G.Shin, Y. J. Kang, W. Kim, J. S. Ha, ACS Nano 2013, 7, 7975.

[5] Y. H. Lee, J.S. Kim, J. Noh, I. Lee, H. J. Kim, S. Choi, J. Seo, S. Jeon, T. S. Kim, J. Y. Lee, J. W. Choi, Nano Lett. 2013, 13, 5753.

[6] L. Yuan, X. Xiao, T. Ding, J. Zhong, X. Zhang, Y. Shen, B. Hu, Y. Huang, J. Zhou, Z. L. Wang, Angew. Chemie 2012, 124, 5018.

[7] N. A. Shepelin, P. C. Sherrell, E. Goudeli, E. N. Skountzos, V. C. Luussini, G. W. Dicinoski, J. G. Shapter, A. V. Ellis, Energy Environ. Sci. 2020, 13, 868.

[8] G. Zhu, B. Peng, J. Chen, Q. Jing, Z. Lin Wang, Nano Energy 2015, 14, 126.

[9] C. Ma, S. Gao, X. Gao, M. Wu, R. Wang, Y. Wang, Z. Tang, F. Fan, W. Wu, H. Wan, W. Wu, InfoMat 2019, 1, 116.

[10] R. Tian, Y. Liu, K. Koumoto, J. Chen, Joule 2019, 3, 1.

[11] M. H. Malakooti, N. Kazem, J. Yan, C. Pan, E. J. Markvicka, K. Matyjaszewski, C. Majidi, Adv. Funct. Mater. 2019, 29, 1.

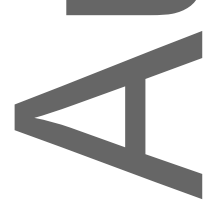

This article is protected by copyright. All rights reserved. 


\section{WILEY-VCH}

[12] M. Zadan, M. H. Malakooti, C. Majidi, ACS Appl. Mater. Interfaces 2020, 12, 17921.

[13] J. Yuan, R. Zhu, Appl. Energy 2020, 271, 115250.

[14] Y. Tang, X. Li, H. Lv, W. Wang, C. Zhi, H. Li, InfoMat 2020, 1.

[15] L. Zhao, H. Li, J. Meng, Z. Li, InfoMat 2020, 2, 212.

[16] Y. Yang, H. Hu, Z. Chen, Z. Wang, L. Jiang, G. Lu, X. Li, R. Chen, J. Jin, H. Kang, H. Chen, S. Lin, S. Xiao, H. Zhao, R. Xiong, J. Shi, Q. Zhou, S. Xu, Y. Chen, Nano Lett. 2020.

[17] N. Kim, S. Lienemann, I. Petsagkourakis, D. Alemu Mengistie, S. Kee, T. Ederth, V. Gueskine, P. Leclère, R. Lazzaroni, X. Crispin, K. Tybrandt, Nat. Commun. 2020, 11, 1424.

[18] M. E. Dupont, D. R. MacFarlane, J. M. Pringle, Chem. Commun. 2017, 53, 6288.

[19] P. Yang, K. Liu, Q. Chen, X. Mo, Y. Zhou, S. Li, G. Feng, J. Zhou, Angew. Chemie 2016, 128, 1.

[20] H. Im, H.G. Moon, J. S. Lee, I. Y. Chung, T. J. Kang, Y. H. Kim, Nano Res. 2014, 7, 443.

[21] M. S. Romano, N. Li, D. Antiohos, J. M. Razal, A. Nattestad, S. Beirne, S. Fang, Y. Chen, R. Jalili, G. G.Wallace, R. Baughman, J. Chen, Adv. Mater. 2013, 25, 6602.

[22] L. Zhang, T. Kim, N. Li, T. J. Kang, J. Chen, J. M. Pringle, M. Zhang, A. H. Kazim, S. Fang, C. Haines, D. Al-Masri, B. A. Cola, J. M. Razal, J. Di, S. Beirne, D. R. MacFarlane, A. GonzalezMartin, S. Mathew, Y. H. Kim, G. Wallace, R. H. Baughman, Adv. Mater. 2017, 29, 1605652.

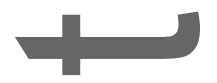

[23] J. Wu, J. J. Black, L. Aldous, Electrochim. Acta 2017, 225, 482.

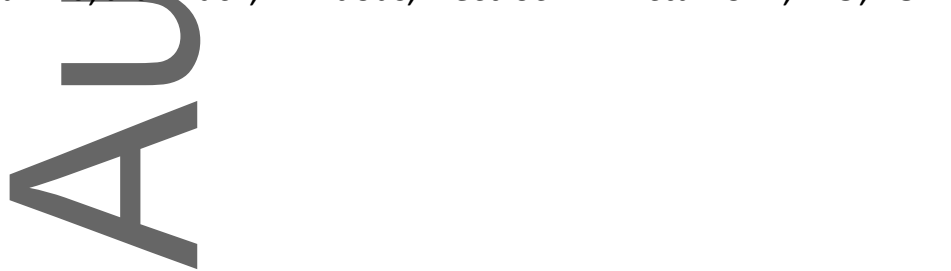

This article is protected by copyright. All rights reserved. 


\section{WILEY-VCH}

[24] M. Russo, H. Warren, G. M. Spinks, D. R. MacFarlane, J. M. Pringle, Aust. J. Chem. 2018, 72, 112.

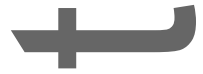

[25] L. Jin, G. W. Greene, D. R. MacFarlane, J. M. Pringle, ACS Energy Lett. 2016, 1, 654.

[26] T. J. Kang, S. Fang, M. E. Kozlov, C. S. Haines, N. Li, Y. H. Kim, Y. Chen, R. H. Baughman, Adv. Funct. Mater. 2012, 22, 477.

[27] H. Im, T. Kim, H. Song, J. Choi, J. S. Park, R. Ovalle-Robles, H. D. Yang, K. D. Kihm, R. H. Baughman, H. H. Lee, T. J. Kang, Y. H. Kim, Nat. Commun. 2016, 7, 10600.

[28] D. P. Dubal, N. R. Chodankar, D. H. Kim, P. Gomez-Romero, Chem. Soc. Rev. 2018, 47, 2065.

[29] J. Duan, B. Yu, K. Liu, J. Li, P. Yang, W. Xie, G. Xue, R. Liu, H. Wang, J. Zhou, Nano Energy 2019, 57, 473.

[30] M. Al Maimani, J. J. Black, L. Aldous, Electrochem. Commun. 2016, 72, 181.

[31] J. H. Kim, T. J. Kang, ACS Appl. Mater. Interfaces 2019, 11, 28894.

[32] J. H. Lee, Y. Jung, J. H. Kim, S. J. Yang, T. J. Kang, Carbon 2019, 147, 559.

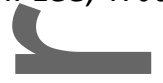

[33] H. Zhou, T. Yamada, N. Kimizuka, Sustain. Energy Fuels 2018, 2, 472.

[34] A. Taheri, D. R. MacFarlane, C. Pozo-Gonzalo, J. M. Pringle, Electrochim. Acta 2019, 297, 669.

[35] K. Wang, X.Zhang, C. Li, X. Sun, Q. Meng, Y. Ma, Z. Wei, Adv. Mater. 2015, 27, 7451. (1)

[36] Q. Tang, M. Chen, G. Wang, H. Bao, P. Saha, J. Power Sources 2015, 284, 400.

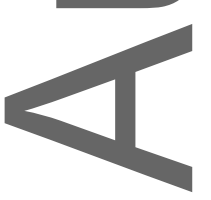

This article is protected by copyright. All rights reserved. 


\section{WILEY-VCH}

[37] Y. Wang, C. Zhu, R. Pfattner, H. Yan, L. Jin, S. Chen, F. Molina-Lopez, F. Lissel, J. Liu, N. I. Rabiah, Z. Chen, J. W. Chung, C. Linder, M. F. Toney, B. Murmann, Z. Bao, Sci. Adv. 2017, 3, e1602076.

[38] J. H. Kim, J. H. Lee, R. R. Palem, M.-S. Suh, H. H. Lee, T. J. Kang, Sci. Rep. 2019, 9, 8706.
(

[39] H. A. H. Alzahrani, M. A. Buckingham, F. Marken, L. Aldous, Electrochem. Commun. 2019, 102, 41.

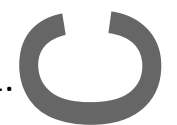

[40] G. Kikugawa, T. G. Desai, P. Keblinski, T. Ohara, J. Appl. Phys. 2013, 114, 034302.

[41] Y. Liu, B. Weng, J. M. Razal, Q. Xu, C. Zhao, Y. Hou, S. Seyedin, R. Jalili, G. G. Wallace, J. Chen, Sci. Rep. 2015, 5, 17045.

[42] V. C Tung, L. M. Chen, M. J. Allen, J. K. Wassei, K. Nelson, R. B. Kaner, Y. Yang, Nano Lett. $2009,9,1949$.

[43] S. Y. Yang, K. H. Chang, H. W. Tien, Y. F. Lee, S. M. Li, Y. S. Wang, J. Y. Wang, C. C. M. Ma, C. C. Hu, J. Mater. Chem. 2011, 21, 2374.

[44] D. Yu, L. Dai, J. Phys. Chem. Lett. 2010, 1, 467.

[45] S. Pu, Y. Liag, K. Chen, J. Fu, S. Zhang, L. Ge, G. Conta, S. Bouzarif, T. Cheng, X. Hu, K. Liu, J. Chen, Nano Lett. 2020, 20, 3791.

[46] A. K. Sundramoorthy, B. S. Premkumar, S. Gunasekaran, ACS Sensors 2016, 1, 151.

[47] M. Sobkowiak, R. Gabrielsson, O. Inganäs, G. Milczarek, Synth. Met. 2014, 194, 170.

This article is protected by copyright. All rights reserved. 


\section{WILEY-VCH}

[48] J. H. Lee, Y. Jung, J. H. Kim, S. J. Yang, T. J. Kang, Carbon 2019, 147, 559.

[49] A. Taheri, D. R. MacFarlane, C. Pozo-Gonzalo, J. M. Pringle, ChemSusChem 2018, 11, 2788.

[50] A. Walker, R. Jalili, S. N. Faisal, G. Ryder, G. G. Wallace, D. L. Officer, International Patent Application, No. PCT/AU2019/051076, 2019.

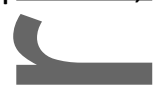

Structure of $p$ - $n$ paired thermo-cells

Integrated thermo-cells with $p-n$ pairs connected in series

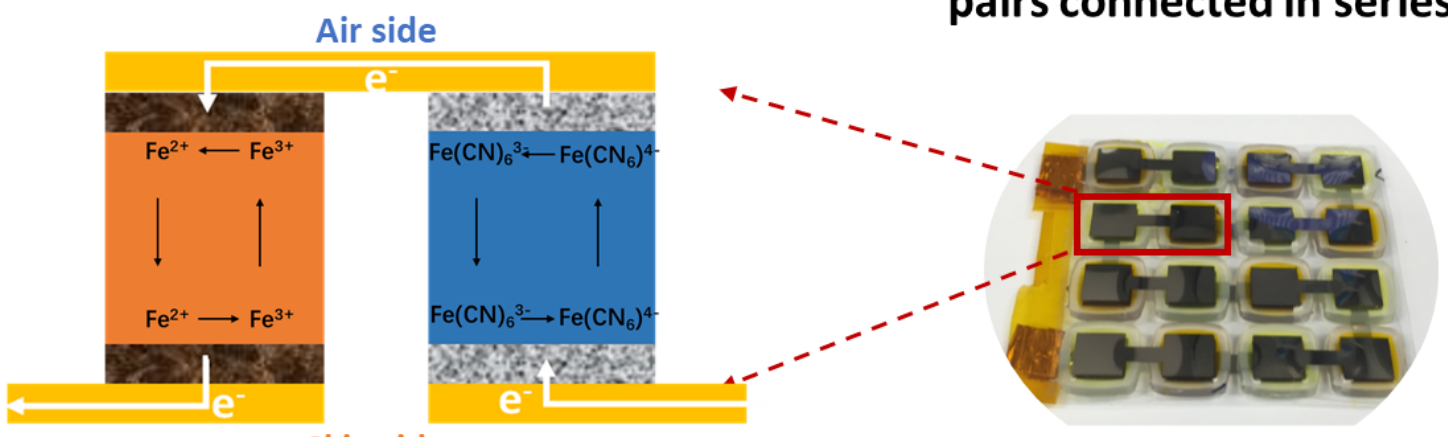

\section{Skin side}

Gel electrolyte and $E$ Electrode for n-type cell

Gel electrolyte and Ess Electrode for p-type cell

Metal current collector

Figure 1. Schematic illustration (left) of the optimization for $p$ - $n$ paired thermo-cells, which is the basic unit of the integrated thermo-cells (right).

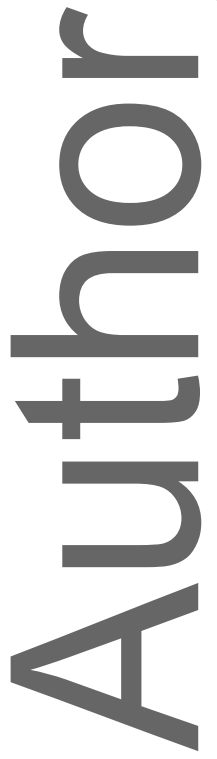

This article is protected by copyright. All rights reserved. 
(a)
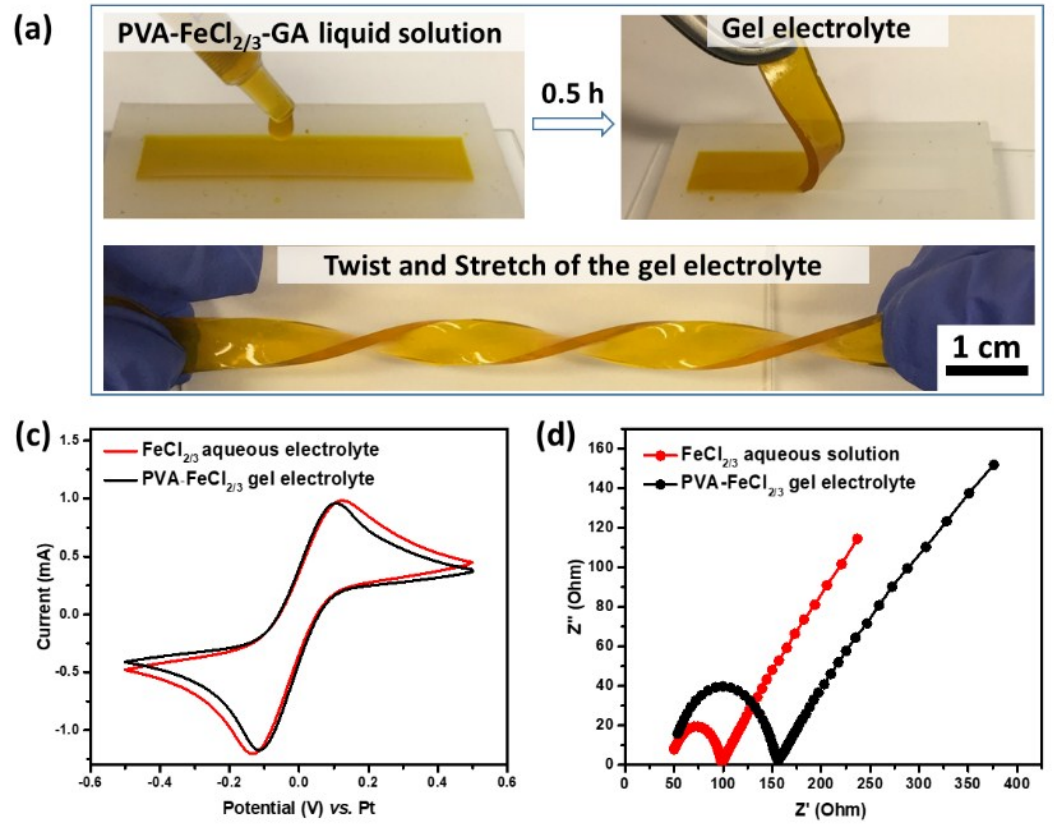

(b)

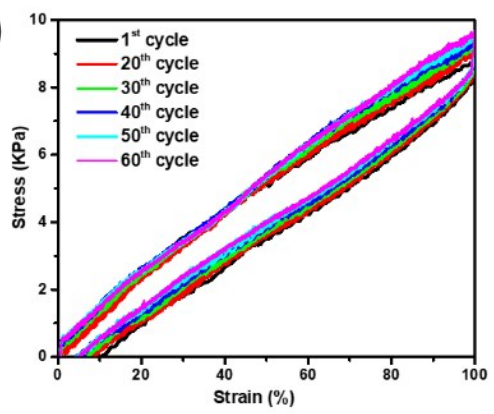

(e)

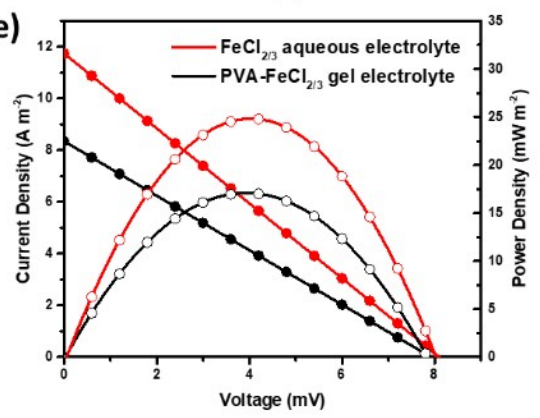

Figure 2. Preparation and characterization of the PVA- $\mathrm{FeCl}_{2 / 3}$ gel electrolyte. a) Illustration of the preparation of the $\mathrm{PVA}-\mathrm{FeCl}_{2 / 3}$ gel electrolyte. b) Stress-strain curves of $\mathrm{PVA}-\mathrm{FeCl}_{2 / 3}$ gel electrolyte (PVA content: 5 wt.\%, $\mathrm{FeCl}_{2 / 3}$ concentration: $1 \mathrm{M}, \mathrm{Mw}=85 \sim 124 \mathrm{kDa}$ ) during 100\% cyclic strain. $\mathrm{c}$ - e) Comparison between $\mathrm{FeCl}_{2 / 3}$ aqueous (concentration: $1 \mathrm{M}$ ) and $\mathrm{PVA}-\mathrm{FeCl}_{2 / 3}$ gel electrolyte (PVA content: 5 wt. $\%, \mathrm{FeCl}_{2 / 3}$ concentration: $1 \mathrm{M}$ ) in terms of c) Cyclic voltammetry (scan rate $=50 \mathrm{mV} \mathrm{s}^{-1}$ ), d) electrochemical impedance spectra, and e) thermo-electrochemical performance: current (solid circle) and power (hollow circle) vs voltage $\left(\Delta \mathrm{T}=10^{\circ} \mathrm{C}\right)$.

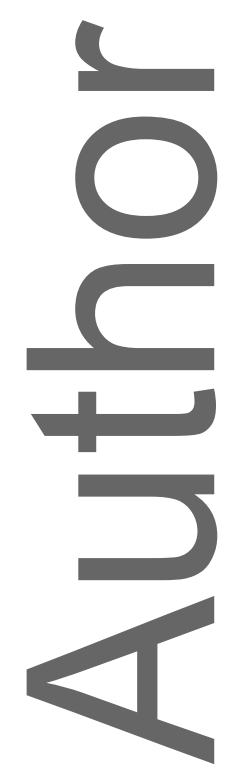

This article is protected by copyright. All rights reserved. 


\section{WILEY-VCH}

(a) Pt on Kapton Tape

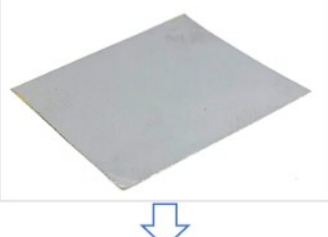

Film Electrode

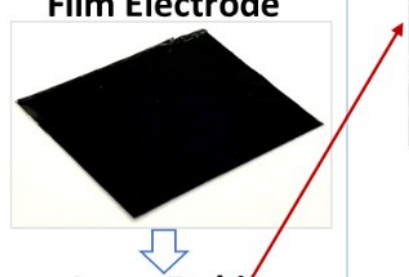

Laser Etching

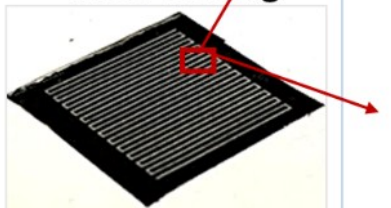

Flexible Film

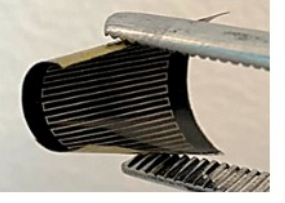

p-type electrode: PEDOT/PSS-EFG/CNT
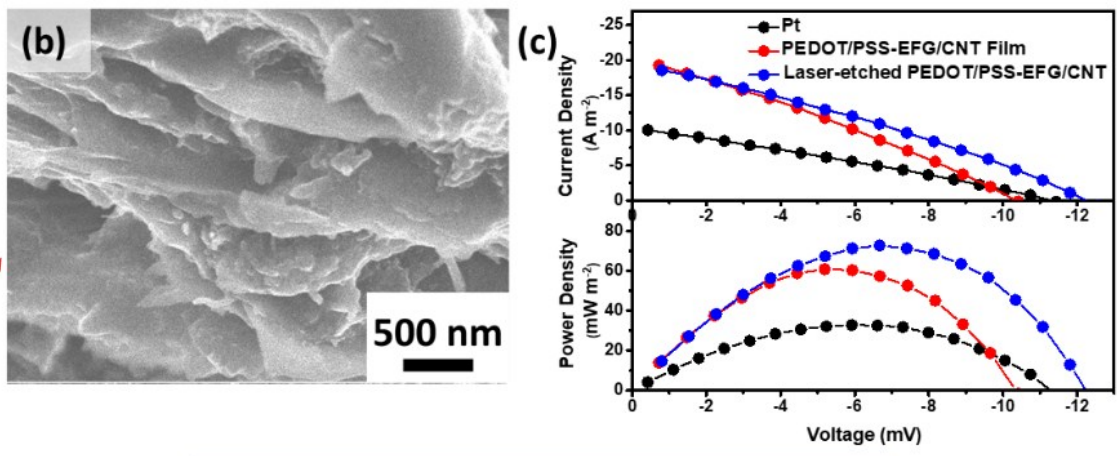

n-type electrode: PEDOT/PSS
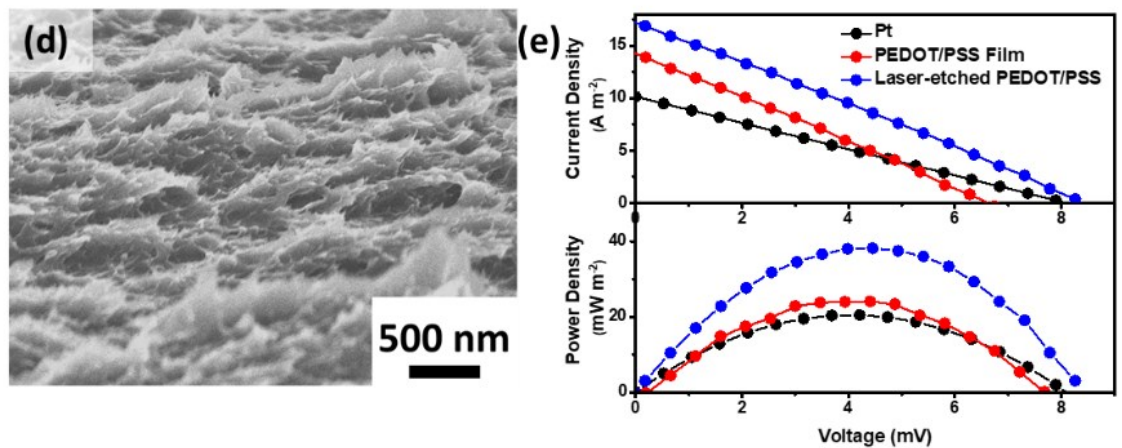

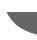

Figure 3. Preparation and characterization of electrodes for p-type and n-type cells. a) Schematic illustration of the preparation of laser-etched film electrode. b) Cross-sectional SEM image of PEDOT/PSS-EFG/CNT film and c) the TEC performance: current and power vs voltage of the devices made from laser-etched PEDOT/PSS-EFG/CNT, PEDOT/PSS-EFG/CNT film and pure Pt electrodes in $p$ type electrolyte $\left(\Delta T=10^{\circ} \mathrm{C}\right)$. d) Cross-sectional SEM image of PEDOT/PSS film and e) TEC performance: current and power vs voltage of the devices made from laser-etched PEDOT/PSS, PEDOT/PSS film and pure Pt electrodes in n-type electrolyte $\left(\Delta T=10^{\circ} \mathrm{C}\right)$.

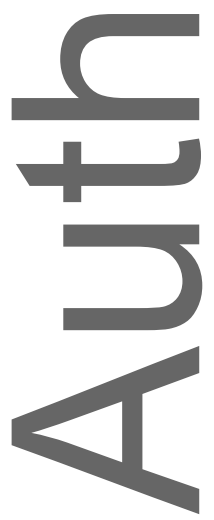

This article is protected by copyright. All rights reserved. 
(a) Structure illustration of a pair of $p-n$ cell
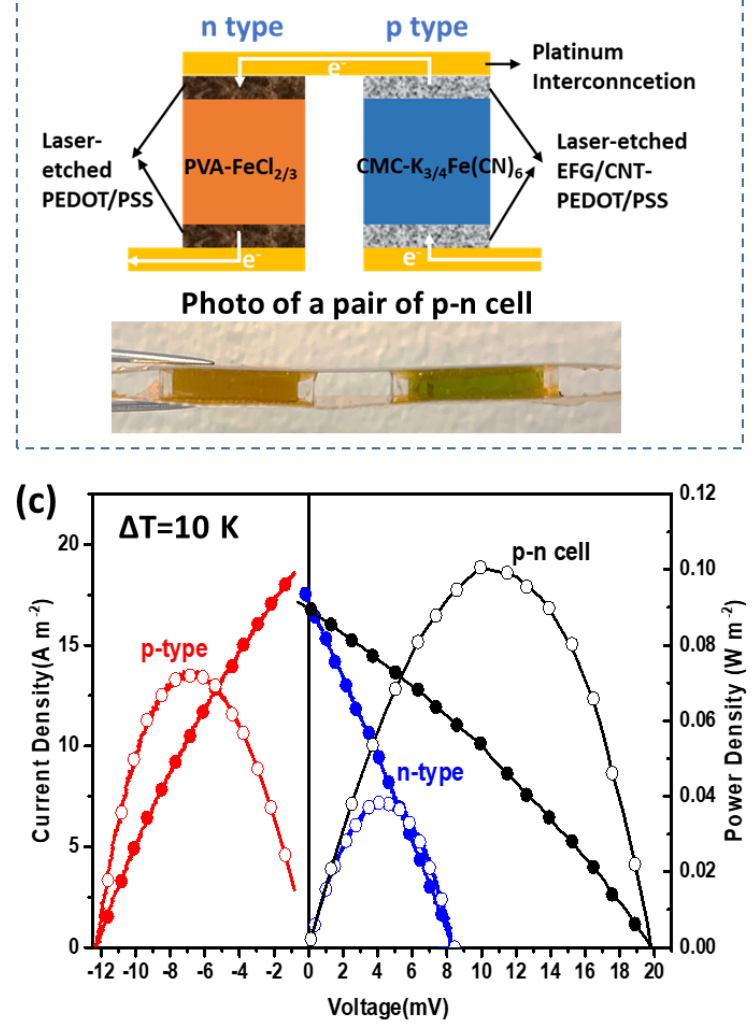

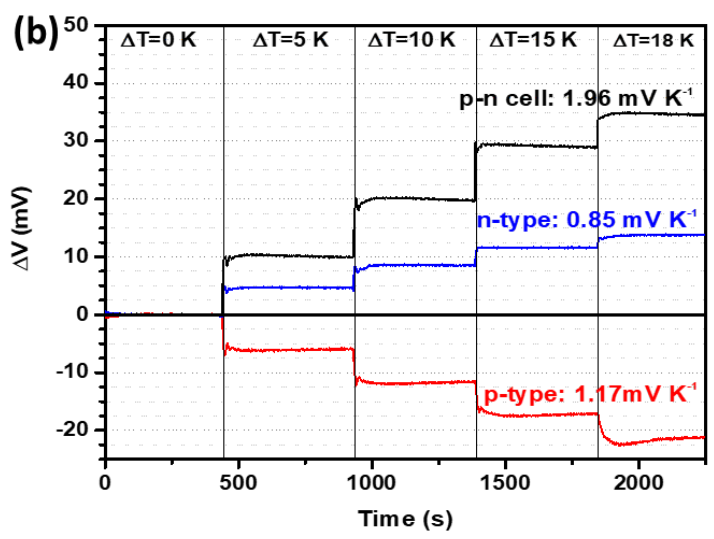

(d)

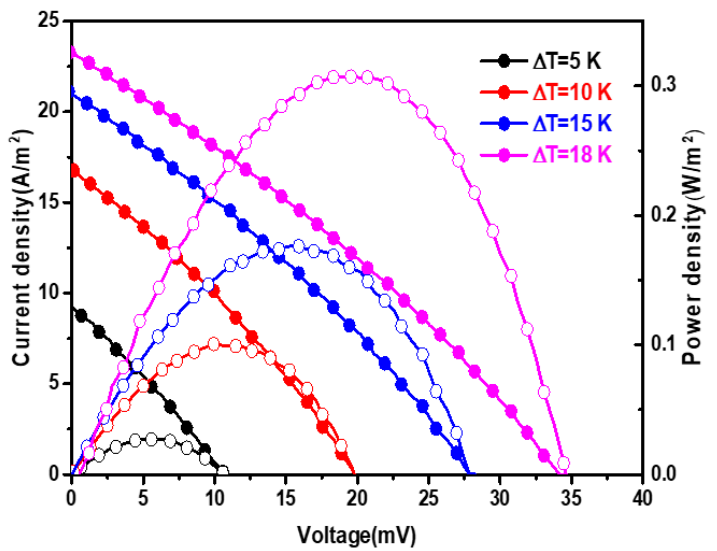

Figure 4. A pair of $p$-n cells. a) Schematic illustration and photo of the $p$-type and $n$-type device connected in series (denoted as $p$-n cell). Thermo-electrochemical performance of the $p$-type, $n$ type, and $p$-n cells showing $b$ ) voltage at different $\Delta T, c$ ) current (solid circle) and power output (hollow circle) Vs voltage at $\Delta T=10 \mathrm{~K}$. d) TEC performance: current (solid circle) and power (hollow circle) vs voltage of $p$-n cell at different $\Delta T$.

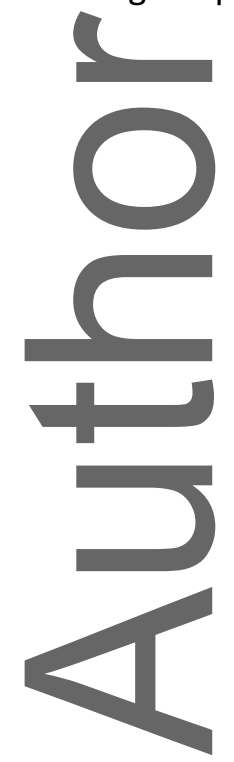

This article is protected by copyright. All rights reserved. 


\section{WILEY-VCH}
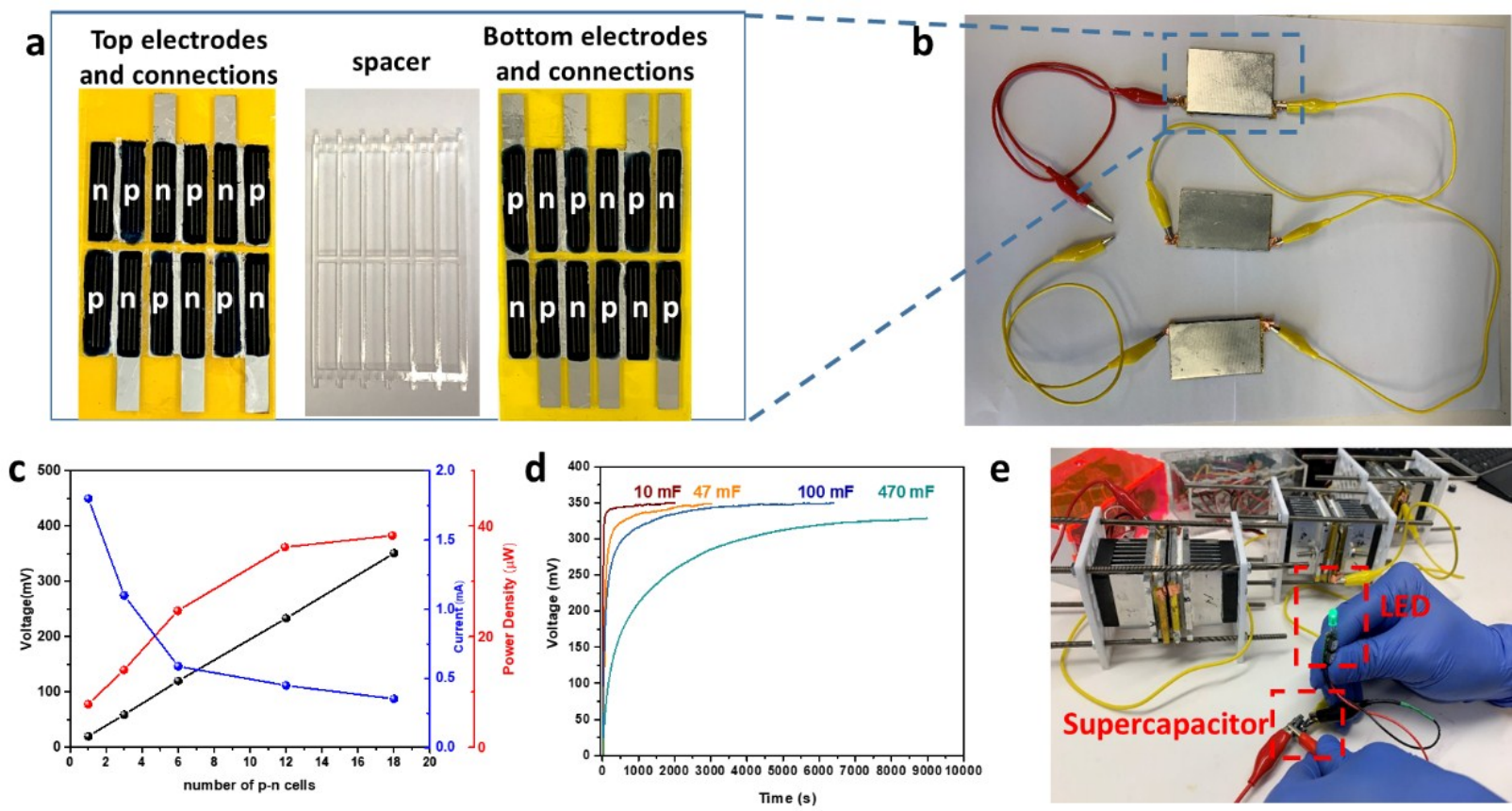

Figure 5. Multiple p-n cells. a) and b) Photos of thermo-cell arrays with 6 pair and 18 pair $p$-n cells connected in series. c) Thermo-electrochemical performance of multiple pairs of $p$-n cells at $\Delta T=10$ $K, d) 18$ pair of $p-n$ cells charging capacitors and supercapacitors with different capacitance, and e) demonstration of thermally charged supercapacitors illuminating a green LED.

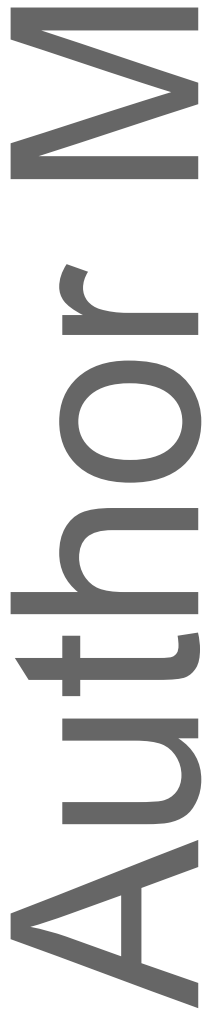

This article is protected by copyright. All rights reserved. 


\section{WILEY-VCH}

(a) Design of flexible watch strap shaped thermo-cells (b) Photos of flexible watch strap shaped thermo-cells
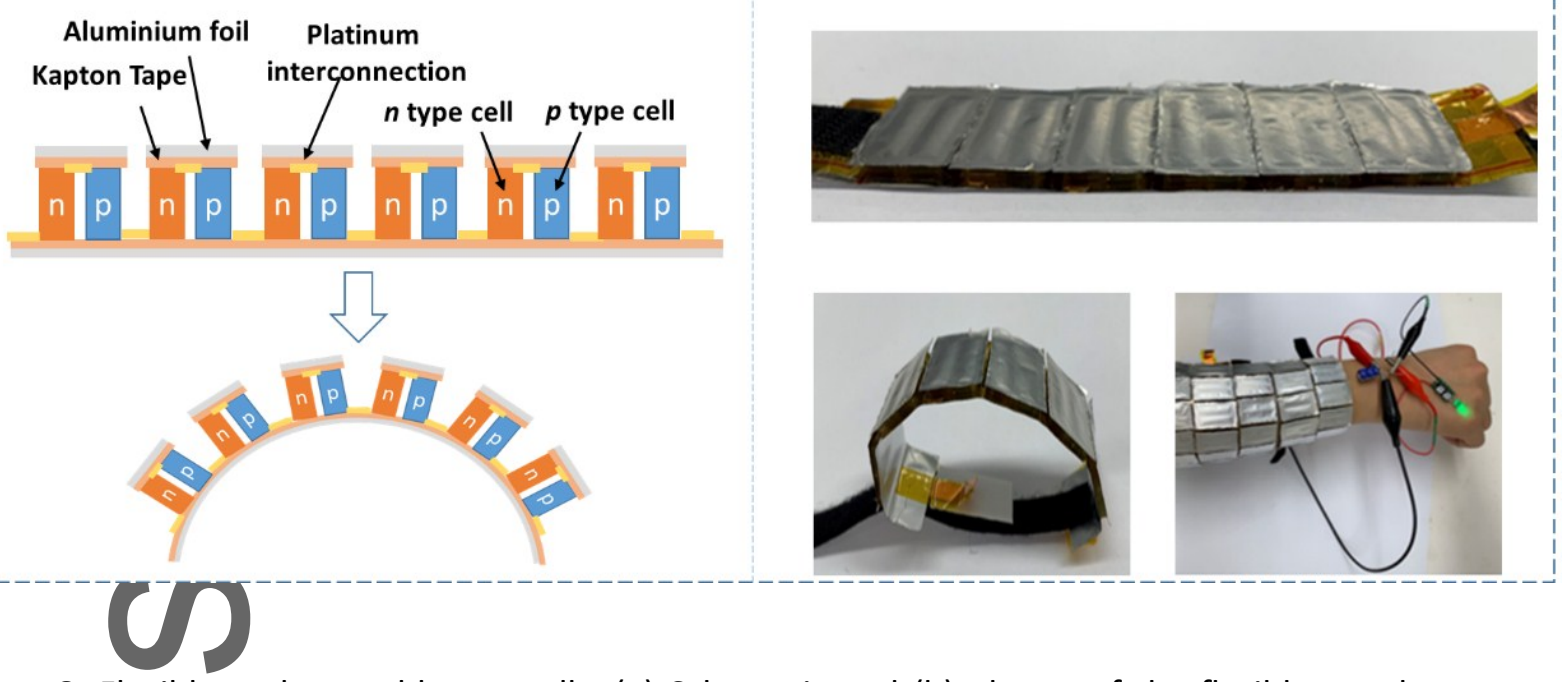

Figure 6. Flexible and wearable p-n cells. (a) Schematic and (b) photos of the flexible watch-strap shaped thermo-cell for body-heat harvesting.

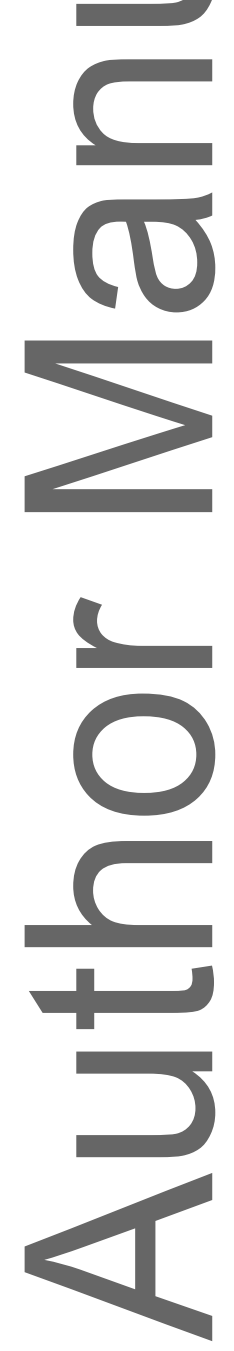

This article is protected by copyright. All rights reserved. 


\section{WILEY-VCH}

A proof-of-concept of high-performance wearable thermo-cells is made through the systematic investigation into wearable thermo-cells with regard to the development of $n$-type gel electrolytes, the integration of gel electrolytes into three-dimensional porous electrode, and advanced device design. The demonstration of wearable thermo-cells harvesting body heat, charging supercapacitors and illuminating LED lights, shows the potential for real application.

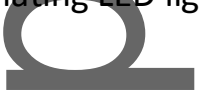

Yuqing Liu ${ }^{1,2^{+}}$, Shuai Zhang ${ }^{2+}$, Yuetong Zhou ${ }^{2}$, Mark A. Buckingham ${ }^{3}$, Leigh Aldous ${ }^{3}$, Peter C. Sherrell ${ }^{4}$, Gordon G. Wallace ${ }^{2}$, , Gregory Ryder, Shaikh Faisal', David L. Officer ${ }^{2}$, Stephen Beirne ${ }^{2}$, and Jun Chen $^{2, *}$

Advanced wearable thermo-cells for body heat harvesting

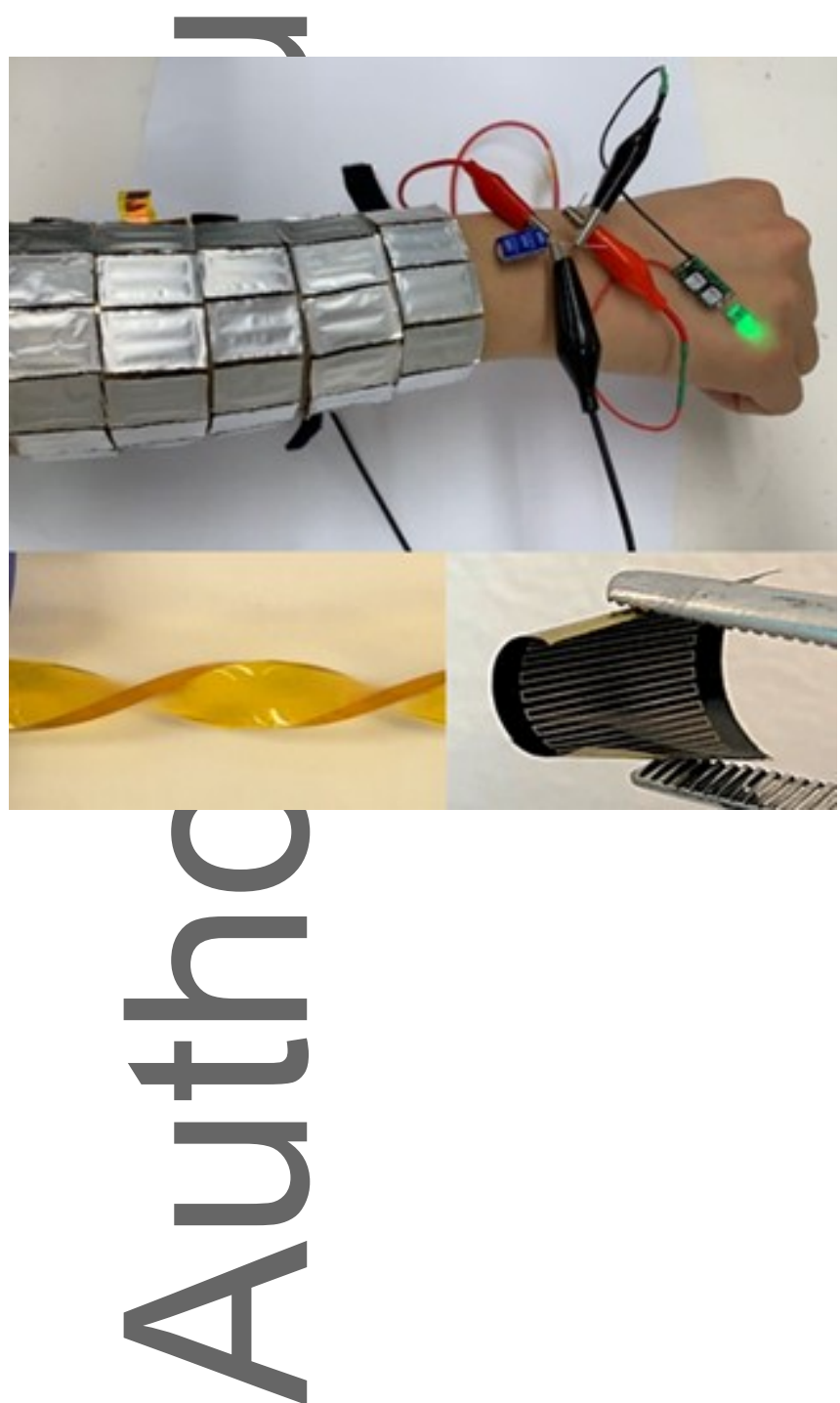

This article is protected by copyright. All rights reserved. 


\section{University Library}

\section{- M M N E R VA A gateway to Melbourne's research publications}

Minerva Access is the Institutional Repository of The University of Melbourne

Author/s:

Liu, Y;Zhang, S;Zhou, Y;Buckingham, MA;Aldous, L;Sherrell, PC;Wallace, GG;Ryder, G;Faisal, S;Officer, DL;Beirne, S;Chen, J

Title:

Advanced Wearable Thermocells for Body Heat Harvesting

Date:

2020-10-01

\section{Citation:}

Liu, Y., Zhang, S., Zhou, Y., Buckingham, M. A., Aldous, L., Sherrell, P. C., Wallace, G.

G., Ryder, G., Faisal, S., Officer, D. L., Beirne, S. \& Chen, J. (2020). Advanced Wearable Thermocells for Body Heat Harvesting. ADVANCED ENERGY MATERIALS, 10 (48), https:// doi.org/10.1002/aenm.202002539.

Persistent Link:

http://hdl.handle.net/11343/276384 